DOI: https://doi.org/10.22182/pnb.2122021.4

Година XII, vol. 21

Прегледни рад

број 2/2021.

стр. $75-97$

\author{
Stevan Nedeljkovic*
}

University of Belgrade - Faculty of Political Science

Marko Dašić

University of Belgrade - Faculty of Political Science

\title{
UNITED STATES AND WAR ON TERROR: COSTS OF THE PYRRHIC VICTORY
}

\begin{abstract}
The withdrawal of American troops from Afghanistan during August 2021 puts an end to the longest war that America has ever fought and the first phase of the Global War on Terrorism. In this regard, two important questions arise, which we will try to answer in this paper. First, what are the main external and internal consequences that the United States has faced due to engaging in the "War on Terror"? Second, did the U.S. achieve its goals in that war? The external effects we have identified are the crisis of global leadership, the weakening of relations with the allies, the growth of China in the lee, and the rise of populism. Among the internal ones, we included the strengthening of the presidential function, the increase of state power, more profound social polarization, an increase in budget expenditures, and a growing deficit, as well as human casualties. In the end, we contributed to the debate on the nature of the U.S. "victory". We are providing the argumentation in the direction that the final output of War on Terror should be named Pyrrhic victory.
\end{abstract}

Keywords: the United States, 9/11, War on Terror, foreign policy, U.S. presidency, global leadership

Contact: stevan.nedeljkovic@fpn.bg.ac.rs 


\section{INTRODUCTION}

September 10, 2001, is described by many Americans as "the last normal day." Everything was so ordinary. Congressmen argued over how to revive the U.S. economy and reduce unemployment. President Bush marked 50 years of alliance with the Australian counterpart and promoted educational reform, while Secretary of Defense Donald Rumsfeld declared "war" on the Pentagon bureaucracy. Impressions and critiques of the romantic drama Pearl Harbor were still being summed up, and the premiere of Harry Potter and the Philosopher's Stone, scheduled for November 2001, was eagerly awaited. According to a survey conducted by Gallup from September 7 to 10, 2001, less than $1 \%$ of Americans mention terrorism as the most critical problem facing the country (Newport 2001). Terrorism has been a distant problem for them, happening in Turkey, Kenya, Yemen, Gaza, or the Philippines. However, on September 11, terrorists struck at the center of U.S. political and economic power. At the same time, they struck at American pride and a sense of security.

America felt wounded and acted like a "wounded beast." Blessed with geography or, as John Mearsheimer puts it, the "stopping power of water" (Mearsheimer 2001, 41) and insufficiently powerful neighbors, Americans did not face a significant attack on its continental territory for almost two centuries. Now they were attacked by an unconventional enemy with unconventional weapons when they were at the peak of their power (Nedeljković 2020). The response of the United States was fierce and often unilateral. This reaction should come as no surprise because, as John Lewis Gaddis (2005) notes, in the circumstances such as the attacks on Pearl Harbor in 1941, faced with direct attacks on their territory, Americans generally respond unilaterally.

Bush's maxim "either you are with us or with the terrorists" was more reminiscent of the imperial behavior of Rome or Napoleon's France than the message of the leader of the beacon of world democracy. However, the War on Terror launch is not an example of George W. Bush's arrogance. According to a survey conducted two days after the terrorist attacks, $93 \%$ of Americans supported a military solution against anyone responsible for the New York and Washington terrorist attacks (Washington Post/ABC News 2001). Moreover, 77\% of respondents said they would support military action even if it meant killing innocent civilians (Washington Post/ABC News 2001). As early as September 14 , in a joint U.S. resolution, the Congress voted (Senate 97-0, House of Representatives 420-1) to authorize the "use of the United States Armed Forces against those responsible for the recent attacks launched against the 
United States "(J.R. 2001). International support was also unprecedented and included rivals such as Russia and China. With such support and wounded pride, a measured reaction could not have been expected.

Twenty years after one of the deadliest terrorist attacks in history, America and the world look significantly different than anyone could have predicted at the time. September 11 triggered a wave of events, actually a tsunami, which had devastating consequences. Some of them are measurable, such as the number of victims or the amount of money spent, while others, such as the lost development potential of societies and individuals, are not. The withdrawal of American troops from Afghanistan during August 2021 puts an end to the longest war that America has ever fought and the first phase of the Global War on Terrorism. In this regard, two important questions arise, which we will try to answer in this paper. First, what are the main external and internal consequences that the United States has faced due to engaging in the "War on Terror "? Second, did the U.S. achieve its goals in that war?

\section{CONSEQUENCES OF THE WAR ON TERROR}

"As we enter the new millennium, we are blessed to be citizens of a country enjoying record prosperity, with no deep divisions at home, no overriding external threats abroad, and history's most powerful military ready to defend our interests around the world. Americans of earlier eras may have hoped one day to live in a nation that could claim just one of these blessings. Probably few expected to experience them all; fewer still all at once" (NSS 2000).

These words begin the preface of the U.S. National Security Strategy presented by the White House in December 2000. Even if we ignore the exaggerations regarding the absence of deep divisions in American society, it cannot be denied that the United States was at the peak of power at the end of the millennium. With the end of the Cold War and the collapse of the Soviet Union, they became the only superpower and the only pole of power in the international system. US GDP was twice as large as Japan's (closest companion) and grew at an annual rate of $4 \%$. U.S. defense spending accounted for $37 \%$ of total world spending (SIPRI 2001). The U.S. had a decisive influence in almost all major international organizations, and the number of American allies continued to multiply. No matter how unusual such a situation was from a historical perspective, other countries did not strive to balance American power. Above all, Americans were optimistic about the future of their family and nation (Pew Research Center 1999), and globalization was increasingly reminiscent of Americanization. 
Nevertheless, Nassim Nicholas Taleb (2007 10) is right when he claims that "history does not crawl, it jumps." Occasionally, black swans appear on the horizon, events that come suddenly, carry a massive impact, and for which we devise post factum explanations, trying to present them as less sudden than they are (Taleb 2007). 9/11 is a typical example of an event that radically transformed U.S. foreign and security policy and the world. The world today is more anarchic and less stable and secure than 20 years ago. On the other hand, the United States does not look good either. The Global War on Terror has exhausted America, so it looks like a tired giant today. Truth be told, the day after the deadly attacks, President Bush warned that War on Terror would be "a monumental struggle of good versus evil," that it would require "time and resolve," and that America would use all available resources to defeat the enemy (Bush 2001). But hardly anyone, including the President himself, expected 20 years of fighting, almost a million civilian and military casualties, and spending of over 8 trillion U.S. dollars.

In this article, we will analyze the main consequences of the U.S. War on Terror. Although the list of challenges that the United States has faced is long and not yet final, we have singled out the key external and internal consequences. The external effects we have identified are the crisis of global leadership, the weaking of relations with the allies, the growth of China in the lee, and the rise of populism. Among the internal ones, we included the strengthening of the presidential function, the increase of state power, more profound social polarization, an increase in budget expenditures, and a growing deficit, as well as human casualties.

\section{THE CRISIS OF GLOBAL LEADERSHIP}

The twentieth century ended with "an extraordinary imbalance in world power resources" (Nye 2014, 118). In terms of hard power, the U.S. was the only state capable of projecting a military force in any corner of the world. At the same time, its economy was vital, and the volume of GDP was as big as the next five largest world economies together. American universities were unrivaled when it came to soft power, while American culture and the entertainment industry flooded the globe. Given the colossal military budget and network of alliances worldwide, "the remaining countries could not create a classical balance to American power" (Nye 2014, 118). America was not only the leader of the free world but a global leader with terrifying power. For the first time since the Peace of Westphalia (1648), the international system had a unipolar structure, and one state was able to shape the game's rules. 
Moreover, other states were willing to accept American leadership voluntarily. It was a time of unipolar (Krauthammer 1990) and liberal moment (Ikenberry 2020, 255)

Twenty years later, many states no longer consider the United States "a leader worth following" (Bremmer 2015). The world today is facing a crisis of American leadership. Of course, the War on Terror is not the only cause of such a situation. Although the United States was seen as a benign hegemon, American power was intimidating to others. By the nature of things, unbalanced power is seen as a danger to others. As Timothy Garton Ash put it, "the main problem with American power is the power itself. It would be dangerous even for an archangel to wield so much power" (Garton Ash 2002). It is also expected that others tended to increase their power. However, American engagement in the War on Terror has significantly undermined the leadership potential of the United States.

One of the transformative moments and key causes of the weakening of the U.S. leadership role in the post-9/11 era was the Iraq War (2003). The aggressive unilateralism of the United States during the preparations for the Iraq War led to other states beginning to perceive the United States as a threat. While America had almost unanimous support for the 2001 invasion of Afghanistan, it gathered a "coalition of the willing" against Iraq. In fact, "a coalition of the anonymous, the dependent, the half-hearted and the uninvolved, whose lukewarm support supposedly confers some moral authority" (Keller 2003). The former maxim of action "multilaterally, when possible, unilaterally when necessary" (Kagan 2004) gave way to the maxim "with us or against," which is more appropriate for imperial powers than for democracies. Initiating an intervention without a Security Council decision provoked disapproval from even close allies like France and Germany. At the same time, Russia and China were concerned about U.S. "imperial temptations" (Snyder 2002).

Iraq has launched a chain of events that has resulted in a series of crises and weakened the U.S. leadership role. It's hard to disagree with Ian Bremmer (2015), who argues that "there was never a golden age of American power when everyone followed America's lead. Even at the height of the Cold War, U.S. allies often defied Washington's wishes." The example of French President Charles de Gaulle is perhaps the most illustrative. However, what is different today is that America is "less able to convene a coalition, forge trade agreements, build support for sanctions, broker compromise on an important multinational dispute, or persuade others to follow it into conflict than at any time in the past seven decades" (Bremmer 2015). 
Finally, perhaps the most significant symbol of the absence of U.S. global leadership is that we are seeing signs of a hard balancing against the U.S. for the first time since the Cold War. The words of Christopher Layne $(2004,119)$ "the Iraq War may come to be seen as a pivotal geopolitical event that heralded the beginning of serious counterhegemonic balancing against the United States" today sound almost prophetic. Russia, China, and other countries are now truly challenging the power of the United States. At the beginning of the third decade of the 21 st century, the world enters a period where many notice the seeds of "Cold War-style global divisions" (Cooley and Nexon 2020, 190). Although the new U.S. president acknowledges that there are areas of cooperation where cooperation with Russia and China is necessary, such as climate change or combating the proliferation of weapons of mass destruction, he also brings together allies and countries that the United States could use in future competition. America will continue to have the ability to gather a strong coalition in the future, but the War on Terror has exhausted the possibility of U.S. global leadership.

\section{THE WEAKENING OF AMERICAN ALLIANCES}

If the terrorist attacks on New York and Washington marked the beginning of the War on Terror, Iraq invasion (2003) could be seen as the beginning of American deviation in that war. At the same time, it was the beginning of aggressive U.S. unilateralism and the loss of international support. As early as December 2001, President Bush, in a meeting with Tommy Franks, a U.S. Army general who headed the United States Central Command from 2000 to 2003, discussed the military option for Iraq (Daalder and Lindsay 2003). The decision to invade Iraq was made in the summer of 2002, regardless of whether the intervention would be approved by the Security Council or not. In addition, the U.S. administration decided to use all resources to achieve its goal and gather as broad an international coalition as possible.

The United States viewed the invasion of Iraq as an extension of the War on Terror. If necessary, by deception and fabrication of facts, they tried to show that there is no peace and security if Saddam does not leave power and that Iraq possesses weapons of mass destruction. However, they did not expect resistance from other great powers, especially not the allies. France and Germany were in the lead among European countries in opposing any solution adopted outside the framework of the United Nations. Moreover, there was a possibility that France would veto and Germany would vote against the United States proposal in the Security Council. 
America responded to such actions with the imperial strategy of divide et impera. While France and Germany have struggled to build European unity over the Iraq war so that, once again, the Common Foreign and Security Policy (CFSP) does not prove ineffective, the United States has undermined that unity. They sought to divide Europe, "punish France and Germany" (Gordon 2007) and gather a "coalition of the willing." They succeeded in that. Europe was divided into old and new, into Europeans and Atlantists. The E.U. consultative and consensus-based foreign policy-making process "proved to be either fictitious or irrevocably broken" (Lewis 2011, 70), and the seeds of mistrust among transatlantic allies were sown.

Until the invasion of Iraq in 2003, there was a belief among the allies about the benign character and liberal foundations of American power. However, Bush's launch of intervention against Iraq turned things around. Iraq was a game-changer. After Iraq, the allies also realized that one word prevailed in the construct "liberal hegemony." Of course, it is the word hegemony (Nedeljkovic 2020). It was increasingly questioned whether hegemony could be liberal or benign. In response to aggressive unilateralism, some European allies of the United States and France, and Germany as influential members of NATO and the E.U. applied a soft balancing strategy. Although France and Germany did not rely on a hard or traditional balancing strategy, such actions of European states were unusual. For the first time, transatlantic allies directly undermined each other's interests and built opposing coalitions (Nedeljkovic 2020).

The war on terror has damaged U.S. relations with several non-European allies. Pakistan supported the invasion of Afghanistan and initially provided operational and logistical support. However, occasional unannounced U.S. airstrikes on Pakistani territory, military confrontations between Pakistani and U.S. troops on the AfghanistanPakistan border, unannounced Operation Neptune Spear and the assassination of Osama Bin Laden, and many other examples have made the mistrust between Pakistan and the United States deepen. It was similar to Saudi Arabia, which rejected the request of the U.S. to invade Iraq from its territory, or Turkey, whose interests in the Middle East were often opposed to the American ones.

In addition, unilateralism and the occasional U.S. foreign policy adventurism, situations in which they undermined the interests of even the closest allies and doubts about whether to fulfill their allied obligations, damaged the U.S. Cold War reputation as a reliable ally (Yahri-Milo 2018). Does that mean the United States has been left without allies? Definitely not. The United States still has the most potent and widespread network of alliances globally, but allied potential and credibility were significantly destroyed during the War on Terror. 


\section{IN THE LEE OF WAR ON TERROR: HOW CHINA BECAME COMPETITOR?}

It is not uncommon to assess the events of $9 / 11$ in terms of their consequences for U.S. foreign policy that the turn towards the War on Terror was, at the same time, a "geopolitical gift" for China. "In terms of geopolitical influence, the CCP has been the biggest beneficiary of the War on Terror", said former deputy national security advisor of Barack Obama, Ben Rhodes (2021). The same China that had been seen after the Cold war as "a weak and impoverished country that had been aligned with the United States against the Soviet Union for over a decade" (Mearsheimer 2021, 48). As Mearsheimer has noted, the rest of the world ignored China's rising population and wealth as building blocks of a strong military. A direct consequence was that, instead of preventing China from becoming more robust and mightier initially, the U.S. and its allies allowed them to challenge the basics of the postCold War war international order. The long establishing multipolarity of the international system is threatened to turn into its antipode: "the new Cold war" with all its echoes of history (Brands, Gaddis 2021). China's success and U.S.'s imprudence share the blame for this turn. "China has always had revisionist goals; the mistake was allowing it to become powerful enough to act on them" (Mearsheimer 2021, 51), but what was the relevance of the War on Terror for letting China become more powerful?

During the 80 s and 90 s, we can notice a kind of continuity in the U.S. economic approach towards China. The same was during the 2000s. Institutionalizing the status of a most favored nation and then allowing membership in World Trade Organization (WTO) were preconditions for the unhampered economic growth of China. One of the main arguments for justifying such liberal views on China's economic development has its ground in the processes of democratization. The wealthier China was, the more democratic its society would be. But, nobody counts with unintended consequences.

Rarely the U.S. presidents were aware of possible policy failures. For example, when "Clinton admitted in 2000, 'We don't know where it's going,' and George W. Bush said the same year, 'There are no guarantees" (Mearsheimer 2021, 54), they weren't even close to assessing future relations among the two powers. Nevertheless, the first decade of the XXI century didn't show any progress in correcting that deficiency. A top priority of the U.S. foreign engagement became the War on Terror. It was a period of blindness to Chinese growth. As 
Rhodes (2021) stated, “ironically, China's ascent in global influence accelerated rapidly after 9/11," and the main reason was the U.S. foreign and security policy focus on terrorism and the Middle East, leaving space for the development of China's influence on numerous regions outside of Asia.

It was completely different a few months before a terrorist attack. On April 1, 2001, a Chinese fighter jet toppled a U.S. reconnaissance plane, detained crew, and inspected in detail the crashed aircraft. It was an announcement of hostility, in case 9/11 had never happened. The U.S. decided to turn attention to the War on Terror, allowing "China's economic and military power grew exponentially" (De Luce 2021).

Interpreting U.S. policy towards China after $9 / 11$ as ignorance, reactive policy, or the inertia of approach from the previous decade would be nothing more than destructive simplification. In that sense, we agree with the argument apprised by Nguyen (2017), which evaluates the first period after the $9 / 11$ attacks in terms of U.S. policy towards Asia as "effectively cooperation with China, substantially enhancing the United States' Asian alliances and extensively engaging with Asian multilateral institutions." The Bush administration changed policy course and also political discourse towards China. While Clinton saw China as a strategic partner, Bush's views strongly differed as he approached China as a strategic competitor. But still, during his two terms as a President, he did much in normalizing relations with China as a rising power. The economy of China was embedded in the international economic and trade system. Bush maintained good personal relations with political representatives of China and was perceived as "a true friend of China" (Demick 2009). There was a gap between discourse and actual actions. We see it mobilizing all efforts in the War on Terror and keeping potential conflicts with rising powers within the regional political and security dynamics and framework of multilateralism. Of course, all the moves of the Bush administration wouldn't be possible without the fact that "The Chinese government quickly expressed sympathy for the human and material loss and took a strong position in support of U.S. efforts to combat international terrorism" (Qinggo 2003, 164).

The U.S. made a mistake with its policy towards China. It's the attitude of many experts in the field of international relations and security theory and practice. We've already elaborated on realism's view through the word of John Mearsheimer. But we can add Kishore Mahbubani, who stated that "It was a huge mistake for the United States to focus on the war on terror, because the real challenge was going to come from China" (cited in: De Luce 2021), or Evan Medeiros who 
thought that the U.S. "gave them 20 years, and we retooled our military for a fight totally irrelevant to the principal security challenge of today" (cited in: De Luce 2021). The change has come with Donald Trump as a president because "he quickly abandoned the engagement strategy that the previous four administrations had embraced, pursuing containment instead" (Mearsheimer 2021, 55). Nevertheless, it seems that it was a late response.

\section{THE WAVES OF POPULISM INSTEAD OF THE NEW WAVE OF DEMOCRACY}

The consequences of the 9/11 terrorist attacks were not geographically limited only to U.S. territory, nor were political repercussions generated only on U.S. political and social systems. The far-reaching impact of this black swan at the beginning of the $21^{\text {st }}$ century is measured by the strength of the processes previously attributed to globalization, democratization, or, for example, industrialization. The creation of the world safe for democracy, which became the purpose of U.S. external (military) action, soon showed its face and, in many cases, turned into a side effect of creating a breeding ground for the flourishing of populist regimes. Therefore, it is not surprising that many authors have noticed in a few cases that "where populist parties were indeed fast claiming legitimacy by pointing to their previous warnings against the evil of Islam" (Bergmann 2020, 105). That wasn't the case only in the countries where U.S. and allies tried to implement regime change strategies. The spillover effect took place in western liberal democracy also. While in Northern Africa and the Middle East region post-9/11 wars "instead of democracy, produced the vacuum into which sectarian and tribal identities could flourish" (Held and McNally 2015), the rest of the world showed a tendency to populism based on the citizen's anxiety, fear and firm rule based on the personalization of power. On the wings of the global War on Terror, leaders from all around the world acted unconstitutionally and, in some cases, took undemocratic measures by virtue of "the cumulative negative impact of the failed post-9/11 wars, the intensification of transnational terrorism, and a growing xenophobic discourse that places virtually all blame for every problem on some form of Other" (Held and McNally 2016).

Several illustrative examples support this view. In the presidential debates in 2002, Marin Le Pen strongly alluded to antiMuslim sentiments, and she was very much in favor of the events in U.S. foreign policy. At the same time, in Italy, Prime minister Silvio Berlusconi leads in his statement that qualifies "Western civilization 
as superior to Islamic culture" (Bergmann 2020, 116). In the far north of Europe, support for Danish Peoples Party was born in Denmark. Similar trends are observed in the actions and rhetorical performances of Norwegian Progress Party officials.

If we look at the development of the situation almost two decades later, a new wave of populism has swept Europe. Although it is difficult to prove the cause-and-effect logic of contemporary events with the 9/11 terrorist attacks and the consequent responses led by the United States, it is clear that this is a chain of events triggered by these events and political change. As David Held in his book on global politics after 9/11 speaks, we testify failed wars, political fragmentation, and the rise of authoritarianism (Held 2016). The U.S. is an exporter of not only good democratic practices but also ugly ones.

9/11 events contributed to the rise of populism and authoritarianism in many ways. First of all, we can notice a revival or born in some parts of the world the anti-Arab and anti-Muslim sentiment in political discourse, mostly among European countries. Strengthening far-right political ideas and their respective election results were an alarm for democracy in those countries. Today, we have rapidly growing literature covering populist regimes and political forces from Italy, Poland, Austria, Hungary, Slovenia, Germany, and the U.S. The final result of those political processes based on extremist ideas, latent violence is that "extreme right-wing ideas were becoming mainstream and were normalized, with far-right political parties gaining representation in more than three dozen national parliaments and the European Parliament" (Miller-Idriss 2021, 54). The American response personalized in the War on Terror created a fertile environment for far-right political articulations. "The attacks were a gift to peddlers of xeno-phobia, white supremacism, and Christian nationalism", as MillerIdriss (2021) stated in her brilliant analysis of the connections between 9/11 events and today's growing political relevance of far-right ideas. In other words, paying attention only to "hunting" terrorists all around the world, left enough space for extremists groups to act undisturbed.

The second populism driving force is the changed political governance style, especially in conduction foreign policy. By creating an atmosphere of fear from "outsiders", individual insecurity, and the need for firm rule in combating threats from, for example, immigrants or terrorist sleeper cells, the leaders simply "opened a door for extremists, who marched right through it" (Miller-Idriss 2021, 63). In order to hold their positions, mainstream political parties are denounced to embrace some extremist ideas. Take Donald Trump as an example. It is generally known that he (mis)used $9 / 11$ events for justifying his intent to shut 
down all Muslim entries to the U.S. during his campaign, saying that “"thousands of people were cheering on 9/11" (Hall 2021, 53). In other words, the essence of populist leaders' operations lies in providing domestic support instead of effectively resolving issues and post-9/11 patterns of politics are the solid ground for that. We completely agree with Hall (2021) when he says that "Trump's foreign policy rhetoric has been largely to appeal to his domestic base and to generate a necessary sense of crisis to mobilize his supporters". Additionally, sawn the seed of hatred to 'Other' enabled leaders "to influence public perceptions and to win votes by questioning the desirability of Muslims in both the USA and Europe, claiming that Muslims' religious and cultural attributes make them unacceptable as neighbors" (Haynes 2020, 1).

\section{THE GROWTH OF PRESIDENTIAL POWER}

One of the most pronounced changes in the American political system after September 11, 2001, is reflected in the increasingly strong position that the executive takes in creating and implementing foreign and security policy. Although numerous lines have been written about changes in the balance between the legislature and the executive, the White House and the State Department, and even among individuals within the President's office and the National Security Council, it is essential for us to here to determine how the President himself procured for its function a handful of powers, changing the normative framework and interpreting it in its favor.

At the very beginning, it is necessary to mention that changes in the balance of branches of government are not new. The aspiration of the executive to seize as wide a range of competencies as possible can be traced, to say the least, to the establishment of the National Security Council during the Harry Truman administration in 1947. Of course, we should not forget the views of the authors who believe that the "power of the Presidency has been expanding from the Founding" (Marshall 2008, 506) or those who have been following this trend since the beginning of the 20th century and "Presidents Theodore Roosevelt and Wood- row Wilson and later with chief executives such as FDR, LBJ, and Reagan" (Oleszek and Oleszek 2009, 273). Numerous mental experiments on the perception of the power of the president lead, even a layman, to conclusions about the constant growth of the power of the executive and the aspiration of each subsequent President to further increase the extended competencies, or at least verify the current situation.

Our aspiration is not a re-reading of the Federalists Papers, an interpretation of the U.S. Constitution, or a chronicle of the legal 
codification of the conduct of foreign affairs. Such an endeavor would require a new study that goes far beyond the scope of the work presented. Instead, we want to point out specific manifestations of the increase in the power of the executive power, with an emphasis on the presidential function, due to the events of 9/11. Discussions about whether terrorist attacks and the need to respond quickly were directly connected with governance changes within the political system continue until today. Framed by broader debates about presidential powers, there is a tendency to establish a direct connection between terror as a threat to national security and the competencies of the President. It is difficult to determine the cause-and-effect relationship. However, it is still possible to say that the declared War on Terror has tremendously changed the patterns of foreign policy decision-making and action in the United States.

Part of the explanation relies on the often criticized vagueness of the Constitution. Namely, Article 2, which determines the competencies of the executive, especially with regard "to take care that the laws are faithfully executed" (Marshal 2008, 509), ultimately leaves the open end in terms of how the President will take care of it. Crises, wars, the use of armed forces, and other cases that require overcoming massive bureaucracies and efficient action affect the growth of presidential powers without the danger of undermining the legitimacy of the President's position, thanks to which many functions have been unnoticed.

The second line of the explanation relies on the detailed interpretation of the growth of the administrative apparatus and the process of bureaucratization of foreign policy. Of course, it is difficult to penetrate through just a few lines into the "the birth of the administrative state" (Pestritto 2007), determine the causes of its "rise and rise" (Lawson 1994), or summarize "milestones in the evolution" (Dudley 2021). It has already been said that the growth of the President's power is partly due to his skill in finding shortcuts in decision-making procedures. However, even if we accept the growth of the administrative state as inevitable, it is clear that the President himself is still at its top. In other words, we agree entirely with the argument that "the expansion of the federal bureaucracy necessarily invests the Presidency with enormous power" (Marshal 2008, 514).

The enumeration could go on almost indefinitely. Access to confidential information, control through the appointment and appointment of administrative officials, a central place in media coverage, the ability to engage armed forces independently of congressional approval, combined with the need to act quickly and efficiently, are 
only additional support to "justify" expanding presidential powers. All of these factors appear to have achieved a synergistic effect after the 9/11 terrorist attacks "with a rallying U.S. citizens, Congress, the world community behind President Bush" (Thuber 2009, 4), giving the then President immeasurable political capital that supports almost $90 \%$ of public support (Pfiffner 2009, 37).

Adverse circumstances created fertile ground for the growth of presidential power. By approving 40 billion dollars to strengthen domestic and international security and allowing the President to start a War on Terror, Congress (un)intentionally added weights to the executive branch and permanently upset the balance in its favor. The blurring of daily politics by the fight against terror was reflected in the fact that "of the 223 presidential statements and press releases, 40 photo ops, and 12 radio addresses that occurred between September 11, 2001, and December 31, 2002, more than half dealt with terrorism at home or abroad" (Wayne 2009, 74) and enabled the further strengthening of the presidential function to the detriment of other branches of government.

Manifestations in which this has become noticeable are numerous, and the most common are: "domestic wiretapping; blocking White House aides from testifying before congressional committees; the practice of rendition; the creation of secret prisons abroad; interpreting or not enforcing, certain provisions of laws as he sees fit" (Oleszek and Oleszek 2009, 273). In addition, the President has, in the throes of "internal" unilateralism. "issued a small avalanche of directives and executive orders: blocking property and prohibiting terroristrelated transactions (EO 13224), establishing an Office of Homeland Security and the Homeland Security Council in the White House (EO 13228), critical infrastructure protection (EO 13231), and designating Afghanistan and its airspace a combat zone (EO 13239)" (Owens 2009, 312).

It was a war against an enemy whose existence was defined by the President's perception, geographically indeterminate, time-varying, and without a clear war goal, in the way that military doctrine proclaims. It was therefore clear that the absence of the traditional congressional declaration of war, which was last used in World War II, would change the previous practice of using force outside the United States and "blurred the line between a metaphor and a legal state (war), thereby providing him with foundational authority for other non-battlefield policies (e.g., military detention policies, suspension of habeas corpus, etc.) (Kassop 2007, cited in: Owens 2009, 315).

What was announced by the initial, necessary action should have been authorized through legal procedures. This was not particularly 
difficult, especially since the Republican majority retained its majority in Congress until the 2006 election. We have already mentioned some decisions shaped by executive powers. Still, we should not forget the legal codification of the new reality made by Congress and particular departments of the executive branch. Enhanced interrogation techniques, military commissions, secret detains of Muslims, domestic surveillance (i.e., President's Surveillance Program (PSP)) (Carlisle 2021) were all products of Department of Justice decisions or President's executive orders authorized congressionally a few years later, during 2006 (i.e., 2006 Military Commissions Act) or at the very beginning in the field of surveillance through Patriot Act in 2001. Acting in such a way, Congress "collectively has acquiesced in its own marginalization "(Owens 2006, 258).

There is quiet consensus that Authorization for Use of Military Force (AUMF) irreversibly expanded presidential powers. Broad, pretty unclear and unprecise for legal codification language such as the definition of potential targets as persons "planned, authorized, committed, or aided the terrorist attacks that occurred on September 11,2001 , or harbored such organizations or persons" (cited in: Carlisle 2021) was suitable terrain for current and all future presidents to lunch military actions all around the world. Afghanistan, Iraq, Yemen, Somalia, Lybia, combating ISIS are just part of the whole list of AUMF in action.

Twenty years later, the situation hasn't changed dramatically. We could say that the public just got used to a new reality of presidential powers to act outside of the U.S. relying on post-9/11 laws. Invoking Arthur M. Schlesinger, famous historian words that the presidency "has come to see itself in messianic terms as the appointed savior of a world whose unpredictable dangers call for a rapid and incessant deployment of men, arms, and decisions behind a wall of secrecy" (Schlesinger 2004, cited in: Genovese 2017, 61) we may conclude that administration changes its presidents but still strive to expand its powers.

\section{HUMAN CASUALTIES AND THE "CREDIT CARD WARS"}

The War on Terror was a war of choice. Of course, it is hard to imagine that the only superpower does not react and does not tend to quickly punish the perpetrators when it is directly attacked on its territory. However, the United States could choose who to attack, when to attack, with which weapons, and how strongly. They could opt for attacks by special operations forces and airstrikes on terrorist strongholds, or for 
invasions and searches of every hole in the world that terrorists were potentially hiding. The United States opted for option two, and that was not unexpected. Suppose we accept Thucydides' (2000 38) claim that the three most powerful motives for war and the initiator of human action, in general, are fear, prestige, and interests. In that case, we will conclude that after the terrorist attacks of 9/11, the U.S. had all three motives. They feared new terrorist attacks, their prestige and pride were hurt, and numerous political and security interests induced a fierce response. The justification for such an aggressive response is and will be debated, but it is hard not to overlook human and economic costs.

In the War on Terror (2001-2021), 7052 American soldiers and 21 civilian officials lost their lives (Crawford and Lutz 2021). Additionally, "more than 50,000 were wounded in action, and more than 30,000 U.S. veterans of post-9/11 conflicts have taken their own lives" (Rhodes 2021, 26). The struggle for the soldiers' life was thus transferred to U.S. soil. The U.S. troops have been killed worldwide, in Iraq, Afghanistan, Pakistan, Syria, Yemen, and other places where the United States and its allies have fought the battle against terrorists. Although the death of every person is a tragedy, in the two-decade war against terrorism, significantly fewer soldiers died than in World War II, World War I, the Vietnam War, or the Korean War, and even less than in the American Revolutionary War. However, the so-called CNN effect, social networks, and the ease of reaching the horrors of war to American citizens made Americans much more sensitive to every victim. This has contributed to the anti-war discourse and the call for America to turn to itself in the presidential campaigns since 2008.

When the trillions spent from Libya to Pakistan are added to the lost lives, it is not surprising that in recent years, the speech of the presidential candidate George McGovern's Come home America has been quoted more and more often. Although the Pentagon or the U.S. government have never given exact figures on how much money was spent in the War on Terror, based on research by the Watson Institute of International and Public Affairs (2021), we can conclude that the total cost exceeds $\$ 8$ trillion. Comparatively, it is slightly more than 533 annual budgets of the Republic of Serbia or almost 15 annual budgets of the United Kingdom. Of the 8,000 trillion, $\$ 5.8$ trillion includes "the estimated direct and indirect costs of spending in the United States post-9/11 war zones, homeland security efforts for counterterrorism, and interest payments on war borrowing" (Crawford 2021) while "future medical care and disability payments for veterans, over the next decades, will likely exceed $\$ 2.2$ trillion in federal spending" (Crawford 2021). 
In addition to the enormous costs, the War on Terror carries one additional problem. Throughout history, the United States has had an economic model "to sustain it with sufficient bodies and cash" for every war, even the American Revolution (Ackerman 2021, 69). The Union fought the Civil War with "the first-ever draft and the first-ever income tax", the Second World War "saw a national mobilization, including another draft, further taxation, and the sale of war bonds". One of the hallmarks of the Vietnam War was "an extremely unpopular draft that spawned an anti-war movement and sped that conflict to its eventual end" (Ackerman 2021, 69). The War on Terror, like all other American wars, had its economic model. It is a model that is financed from the budget deficit.

In the last two decades, the budget deficit of the United States amounts to close to 18 trillion dollars. In addition to the War on Terror, the remediation of the consequences of the global economic and financial crisis and the coronavirus pandemic contributed to the enormous deficit. However, the lion's share has been spent around the world in the fight against terrorism. The economic model according to which the war is financed from the budget deficit is already showing consequences. Although the ballooning national deficit has "anesthetized the American people to the fiscal cost of the War on Terror" (Ackerman 2021, 69), the indirect consequences could not be obscured. The status of the middle class in the United States has not been improved for decades. Health-care and infrastructure are in a rather bad condition, while about $15 \%$ of the foreign debt is owed to the main global challenger, China. Therefore, it is not surprising that both the government and American citizens have become less and less inclined to foreign policy adventurism in recent years.

\section{CONCLUSION: DID UNITED STATES WIN WAR ON TERROR?}

Under normal circumstances, the answer to the question we ask in the conclusion is relatively easy. The winner of a war is the state or group of states that defeat an enemy on the battlefield and dictate the conditions of peace. Conditions can be just or unjust, they can be the foundation of peace or the seed of new conflicts, but it is clear who is the winner and the loser. In the War on Terror, the answer to the question of who won is not apparent. But asking who lost, it is somewhat clearer. Looking at the goals and expectations before the terrorist attacks on September 11, it seems that Al Qaeda has been defeated. Analyzing bin Laden's correspondence, Nelly Lahoud (2021 13) states that "bin 
Laden never anticipated that the United States would go to war in response to the assault. Indeed, he predicted that in the wake of the attack, the American people would take to the streets, replicating the protests against the Vietnam War and calling on their government to withdraw from Muslim-majority countries ". 9/11 was just a Pyrrhic victory for al Qaeda, but they lost the war. The leadership of this terrorist organization was killed or fled and hid throughout the Middle East in the post-9/11 period, and Al Qaeda has never regained its former strength. Except in Kenya in 2002, al-Qaeda failed to launch a massive attack abroad. Most importantly, the United States did not withdraw from the Muslim world, which was the primary goal of this terrorist organization. Moreover, the United States appears to be more present in the Middle East than before 9/11. Bin Laden changed the world, "just not in the ways that he wanted" (Lahoud 2021, 13).

Given that al-Qaeda did not win, the question arises whether the United States won the War on Terror? In the early years of the War on Terror, the United States seemed to be winning. The Taliban regime fell quickly, as did Saddam Hussein's dictatorial regime. Al-Qaeda was retreating and hiding. However, over time, U.S. goals began to expand, the war turned into decades of agony, and the question of Can the War on Terror Be Won (Gordon 2007a, 53) became more relevant. When the Middle East ended up in flames after the Arab Spring and the rise of ISIS, views on American victory were less and less justified. In the end, the painful withdrawal from Afghanistan in August 2021 made many Americans feel defeated.

For all these reasons, the question of America's victory in the Global War on Terror is not easy. The question of goals precedes the answer to the question of victory. What was the goal of the United States in the War on Terror? Assuming that the U.S. had maximalist goals - eliminating all terrorists, eliminating the terrorist threat, discrediting terrorist ideology, and democratizing the Middle East we can certainly say that America did not win. On the other hand, if the U.S. had minimalist goals - eliminating those responsible for the 9/11 attacks, punishing al-Qaeda shelter states, preventing new major terrorist attacks, and strengthening U.S. security - then America won the War on Terror. Bin Laden and others responsible for the 9/11 attacks were punished, as were the regimes that provided refuge to al-Qaeda. After 9/11, a total of 107 Americans were killed in jihadist attacks on American soil, almost half of them in the attack of Omar Mateen, an American citizen who declared allegiance to ISIS (Byman 2021, $34)$.

Terrorism is a lesser threat to the United States today than it was 
on the eve of $9 / 11$, but the price paid by the Americans is enormous. Al-Qaeda was defeated in battles around the world, but given the price paid, it must be noted that the victory that the United States won in the War on Terror is nothing but Pyrrhic.

\section{REFERENCES}

A National Security Strategy for a Global Age [NSS], December 2000, https:// history.defense.gov/Portals/70/Documents/nss/nss2000.pdf?ver=vuu1vG IkFVV1HusDPL21Aw\%3d\%3d, Last accessed November 5, 2021.

Ackerman, Elliot. 2021." Winning Ugly - What the War on Terror Cost America." Foreign Affairs. 100 (5): 66-74.

Bergmann, Eirikur. 2020. Neo-Nationalism: The Rise of Nativist Populism, New York: Palgrave Macmillan.

Bradley, Curtis A., Trevor W. Morrison. 2013. "Presidential Power, Historical Practice, and Legal Constraint”. Columbia Law Review 113 (4): 10971161.

Brands, Hal, John Lewis Geddis. 2021. "The New Cold War: America, China and the Echoes of History". Foreign Affairs 100 (6): 10-20.

Bremmer, Ian. 2015. Superpower: Three Choices for America's Role in the World. New York: Portfolio.

Bush, George W. 2001.” The Deliberate and Deadly Attacks...Were Acts of War." American Rhetoric. Last accessed November 5 2021. https://www. americanrhetoric.com/speeches/gwbush911 cabinetroomaddress.htm.

Byman, Daniel. 2021. "The Good Enough Doctrine Learning to Live With Terrorism." Foreign Affairs. 100 (5): 32-43.

Carlisle, Madeleine, 2021. "How 9/11 Radically Expanded Power of U.S. Government". Time. September 11. https://time.com/6096903/september11-legal-history/.

Coolay, Alexander and Daniel Nexon. 2020. Exit from hegemony: the unraveling of the American global order. Oxford: Oxford University Press.

Crawford, Neta C. and Catherine Lutz." Human Cost of Post-9/11 Wars." Watson Institute of International and Public Affairs. Last accessed November 5 2021. https://watson.brown.edu/costsofwar/files/cow/imce/ papers/2021/Costs\%20of\%20War_Direct\%20War\%20Deaths_9.1.21. pdf.

Crawford, Neta C." The U.S. Budgetary Costs of the Post-9/11 Wars." Watson Institute of International and Public Affairs. Last accessed November 5 2021. https://watson.brown.edu/costsofwar/files/cow/imce/ papers/2021/Costs $\% 20$ of $\% 20$ War_U.S.\%20Budgetary\%20Costs $\% 20$ of\%20Post-9\%2011\%20Wars_9.1.21.pdf.

Daalder, Ivo A. and James M. Lindsay. 2003. America Unbound: The Bush Revolution in Foreign Policy. Washington, D.C.: Brookings Institution 
Press.

De Luce, Brian. 2021. “After 9/11, China grew into superpower as a distracted U.S. fixated in terrorism, expert say". NBS News October, 17. https:// www.nbcnews.com/politics/national-security/after-9-11-china-grewsuperpower-distracted-u-s-fixated-n1278671

Demick, Barbara. 2009. "In China, Bush remains popular president". Los Angeles Times. January, 15. https:/www.latimes.com/archives/la-xpm2009-jan-15-fg-uschina15-story.html

DePlato, Justin. 2015. American Presidential Power and the War on Terror: Does the Constitution Matter? New York: Palgrave Macmillan.

Dudley, Susan E. 2021. "Milestones in the Evolution of the Administrative State", Daedalus, 150 (3), 33-48.

Gaddis, John Lewis. 2005. Surprise, Security, and the American Experience. Cambridge: Harvard University Press.

Garton, Ash Timothy. 2002. "U.S. and the Hyperpower." The Guardian. https:// www.theguardian.com/world/2002/apr/04/usa.comment.

Genovese, Michael A., David Gray Adler. 2017. The War Power in an Age of Terrorism: Debating Presidential Power. New York: Palgrave Macmillan.

Gordon, Philip H. 2007. "'Punish France, Ignore Germany, Forgive Russia' No Longer Fits." The Brookings Institution. https://www.brookings.edu/ opinions/punish-france-ignore-germany-forgive-russia-no-longer-fits.

Gordon, Philip H. 2007a. "Can the War on Terror Be Won? How to Fight the Right War." Foreign Affairs. 86 (6): 53-66.

Hall, Johnny. 2021. "In search for enemies: Donald Trump's populist's foreign policy rhetoric". Politics 41 (1): 48-63.

Haynes, Jeffrey. 2020. "Right-Wing Populism and Religion in Europe and the USA". Religions 11 (10): 1-18.

Held, David and Kyle McNally. 2015. "9/11 Wars: A Reckoning” Social Europe. March 13. https://socialeurope.eu/911-wars-a-reckoning

Held, David and Kyle McNally. 2016. "Path to authoritarianism: the collapse of the politics of accommodation". Open democracy. September 13. https://www.opendemocracy.net/en/can-europe-make-it/path-toauthoritarianism-collapse-of-politics-of-accommod/

Held, David. 2016. Global Politics After 9/11: Failed Wars, Political Fragmentation, and the Rise of Authoritarianism. London: Global Policy.

Hiland, Alexander. 2020. Presidential Power, Rhetoric and the Terror Wars: The Sovereign Presidency. New York: Lexington Books.

Ikenberry, John G. 2020. A World Safe for Democracy: Liberal Internationalism and the Crisis of Global Order. New Haven: Yale University Press.

Joint Resolution to authorize the use of United States Armed Forces against those responsible for the recent attacks launched against the United States [J.R.], September 18, 2001, https:/www.govinfo.gov/content/pkg/ PLAW-107publ40/pdf/PLAW-107pub140.pdf, Last accessed November 5 2021. 
Kagan, Robert. 2004." America's Crisis of Legitimacy." Foreign Affairs 83 (2): 65-87.

Keller, Bill, 2003." Why Colin Powell Should Go." The New York Times. https://www.nytimes.com/2003/03/22/opinion/why-colin-powell-shouldgo.html.

Kennedy, Brandon. 2012. "The Hijacking of Foreign Policy Decision Making: Groupthink and Presidential Power in the Post-9/11 World". Southern California Interdisciplinary Law Journal 21: 633-680.

Krauthammer, Charles. 1990.” The Unipolar Moment." Foreign Affairs 70 (1): 23-33.

Lahoud, Nelly. 2021. "Bin Laden's Catastrophic Success: Al Qaeda Changed the World-but Not in the Way It Expected." Foreign Affairs. 100 (5): 10-21.

Lawson, Gary. 1994. "The Rise and Rise of the Administrative State", Harvard Law Review 107 (6): 1233-1237.

Layne, Christopher. 2004. „The War on Terrorism and the Balance of Power: The Paradoxes of American Hegemony", In Balance of Power: Theory and Practice in the 21st century. eds. T.V. Paul, James J. Wirtz and Michael Fortmann, 107-121. Stanford: Stanford University Press.

Lewis, Jeffrey. 2011." EU Policy on the Iraq War and its Aftermath: The Breakdown and Revival of Consensus-based Decision-making." In: Making E.U. Foreign Policy: National Preferences, European, Norms, and Common Policies, ed. Thomas C. Daniel, 70-91. New York: Palgrave Macmillan.

Marshall, William P. 2008. "Eleven Reasons Why Presidential Power Inevitably Expands and Why It Matters", Boston University Law Review 88: 505-522.

Mearsheimer, John J. 2021. "The Inevitable Rivalry: America, China, and the Tragedy of Great-Power Politics". Foreign Affairs 100 (6): 48-58.

Miller-Idriss, Cynthia. 2021. "From 9/11 to 1/6: The War on Terror Supercharged the Far Right". Foreign Affairs 100 (5): 54-64.

Nedeljković, Stevan. 2020. „Strategija uravnotežavanja u međunarodnim odnosima, studija slučaja: francusko i nemačko uravnotežavanje Sjedinjenih Američkih Država posle Hladnog rata." Doktorska disertacija. Univerzitet u Beogradu: Fakultet političkih nauka.

Newport, Frank. 2001. "Bush Job Approval Was at 51\% Immediately Before Tuesday's Attacks." Gallup. https://news.gallup.com/poll/4882/bush-jobapproval-51-immediately-before-tuesdays-attacks.aspx. Last accessed November 52021.

Nguyen, Thi Thuy Hang. 2017. "George W. Bush and Asia: In the Shadow of the September 11". Asian Affairs 48 (2): 313-333.

Nye, Joseph S. Jr. 2014." Transformational and transactional presidents." Leadership. 10 (1): 118-124.

Oleszek, Mark J. and Walter J. Oleszek, "Congress and the President: "Yes We Can!" or "Can We?"” in Rivals for Power: Presidential- 
Congressional Relations. ed. Thurber, James A., 251-284. New York: Rowman\&Littlefield Publishers, Inc.

Owens, John E. 2006. "Presidential Power and Congressional Acquiescence in the "War" on Terrorism: A New Constitutional Equilibrium?. Policy \& Politics 34 (2): 258-303.

Owens, John E. 2009. "Rivals Only Sometimes: Presidentialism, Unilateralism, and Congressional Acquiescence in the U.S. "War on Terror"'. in Rivals for Power: Presidential-Congressional Relations. ed. Thurber, James A., 309-324. New York: Rowman\&Littlefield Publishers, Inc.

Pestritto, Ronald. 2007. "The Birth of the Administrative State: Where It Came From and What It Means for Limited Government", The Heritage Foundation. https://www.heritage.org/political-process/report/the-birththe-administrative-state-where-it-came-and-what-it-means-limited. Last accessed September 12, 2021.

Pew Research Center Report. 1999." Optimism Reigns, Technology Plays Key Role.” Pew Research Center. Last accessed November 5 2021. https:// www.pewresearch.org/politics/1999/10/24/optimism-reigns-technologyplays-key-role/.

Pffifner, James P. 2009. "Partisan Polarisation, Politics, and the Presidency: Structural Sources of Conflict". in Rivals for Power: PresidentialCongressional Relations. ed. Thurber, James A., 37-59. New York: Rowman\&Littlefield Publishers, Inc.

Qinggo, Jia. 2003. "The impact of 9-11 on Sino-US relations: a preliminary assessment". International Relations of the Asia-Pacific 3: 159-177.

Rhodes, Ben. 2021. "Them and U.S.: How America Lets Its Enemies Hijack Its Foreign Policy". Foreign Affairs 100 (5): 22-31.

SIPRI. 2001." Military expenditure and arms production." Stockholm International Peace Research Institute. Last accessed November 52021. https://www.sipri.org/yearbook/2001/04.

SIPRI. 2021." World military spending rises to almost \$2 trillion in 2020." Stockholm International Peace Research Institute. Last accessed November 5 2021. https://www.sipri.org/media/press-release/2021/ world-military-spending-rises-almost-2-trillion-2020.

Snyder, Jack. 2003." Imperial Temptations." The National Interest. 71: 29-40.

Taleb, Nassim Nicholas. 2007. The Black Swan: The Impact of the Highly Improbable. New York: Random House.

The Washington Post/ABC. 2001." Post-ABC Poll: Terrorist Attacks." The Washington Post. Last accessed November 5 2021. https://www. washingtonpost.com/wp-srv/politics/polls/vault/stories/data091401.htm.

Thucydides (translated by Martin Hammond) 2009. The Peloponnesian War. Oxford: Oxford University Press.

Thurber, James A., ed. 2009. Rivals for Power: Presidential-Congressional Relations. New York: Rowman\&Littlefield Publishers, Inc.

Watson Institute of International and Public Affairs [WIIPA]. 2021." Costs of War." Brown University. Last accessed November 5 2021. https://watson. 
brown.edu/costsofwar/figures/2021/BudgetaryCosts.

Wayne, Stephen J. 2009. "From Washington to Obama: The Evolution of the

Legislative Presidency”. in Rivals for Power: Presidential-Congressional

Relations. ed. Thurber, James A., 61-81. New York: Rowman\&Littlefield Publishers, Inc.

Yahri-Milo, Keren. 2018. "After Credibility: American Foreign Policy in the Trump Era." Foreign Affairs. 97 (1): 68-77.

\section{Стеван Недељковић*}

Универзитет у Београду - Факултет политичких наука

Марко Дашић

Универзитет у Београду - Факултет политичких наука

\section{СЈЕДИҢЕНЕ ДРЖАВЕ И РАТ ПРОТИВ ТЕРОРИЗМА: ЦЕНА ПИРОВЕ ПОБЕДЕ}

\section{Резиме}

Повлачење америчких трупа из Авганистана током августа 2001. године ставило је тачку на најдужи рат који је САД икада водила, као и на прву фазу глобалног рата против тероризма. У том смислу, јављају се два важна питања, на која ћемо покушати да одговоримо у овом раду. Прво, које су кључне спољне и унутрашње последице са којима се САД суочавају због рата против тероризма? Друго, да ли су САД постигле своје циљеве у том рату. Спољни ефекти које смо идентификовали су криза глобалног лидерства, слабљење односа са савезницима, раст Кине и раст популизма. Међу унутрашњим, издвајају се јачање председничке функције, повећање моћи државе, друштвена поларизација, повећање буџетске потрошње и растући дефицит, као и људске жртве. На самом крају, допринели смо дебати о природи америчке „победе“ у рату против тероризма, аргументујући да финални исход треба да буде сматран „Пировом победом“.

Кључне речи: САД, 11. септембар, рат против тероризма, спољна политика, амерички председник, глобално лидерство

Контакт: stevan.nedeljkovic@fpn.bg.ac.rs

Овај рад је примљен 12. новембра 2021. године, а прихваћен за штампу на телефонском састанку Редакције, 15. новембра 2021. године. 